\title{
An Evaluation of Color Changes of Silicone Maxillofacial Materials after Exposure to Sunlight
}

\author{
Tetsuya TAKAMATA*, B. Keith MOORE** and Varoujan A. CHALIAN*** \\ *Department of Complete and Partial Denture Prosthodontics, Matsumoto Dental College, 1780 \\ Gobara, Hirooka, Shiojiri, Nagano, 399-07, Japan \\ **Department of Dental Materials, Indiana University, School of Dentistry, 1121 West Michigan Street, \\ Indianapolis, Indiana 46202, U.S. A. \\ ***Department of Maxillofacial Prosthetics, Indiana University, School of Dentistry, 1121 West \\ Michigan Street, Indianapolis, Indiana 46202, U. S. A.
}

Received on July 21, 1989

Accepted on October 13, 1989

A number of authors have listed the following qualities as ideal for maxillofacial material : (1) original physical and mechanical properties comparable to the human tissue that they are replacing, (2) the ability to sustain these properties during service, (3) compatibility with human tissues and the adhesives used to adhere the prostheses to tissue, and (4) the quality of being easy to process and an insensitivity to processing variables. Clinical experience has indicated that there is frequent and for the replacement of maxillofacial appliances because of rapid discoloration in the service environment and/or degradation of the physical and dynamic properties of the base elastomer. Color stability in the service environment may be the most important factor in patient acceptance of the prosthesis. The results of this study suggested that aging rather than exposure to sunlight results in most of the color changes observed in the HTV and RTV base polymers studied.

Key words : Color change, Silicone material, Maxillofacial prosthesis

\section{INTRODUCTION}

The ideal material for an external maxillofacial prosthesis is one which incorporates the following properties: biocompatibility; strength and flexibility; durability; low weight; resistance to chemical and environmental agents; ease in manipulation, fabrication, and cleansing, and natural appearance and texture ${ }^{1-3}$. To evaluate these characteristics, it is necessary to make longterm observations.

Clinical experience has indicated the need for frequent replacement of maxillofacial appliances because of rapid discoloration in the service environment and/or degradation of the physical and dynamic properties of the base elastomer. Color stability in a service environment may be the most important factor determining a patient's acceptance of a prosthesis. There are many studies discussing the color of maxillofacial materials ${ }^{4-17}$, but there are few articles dealing with the effects of sunlight ${ }^{18)}$. Currently, the most widely used materials for maxillofacial prosthetics are polysiloxane, polyurethane, and polyvinylchloride ${ }^{19)}$. Recently, room temperature vulcanizing silicone, RTV silicone*, has been made commercially available ; and because it is a remarkable improvement over older polymers, it is becoming increasingly used in maxillofacial clinics. Although RTV has the advantages of allowing repeatable intrinsic coloration and easy molding, it is limited by its lack of strength, the time required for mixing and manipulation, and its short pot life ${ }^{201}$. 
Scientific investigation and clinical experience have shown the superiority of high temperature vulcanizing silicone, HTV silicone ${ }^{* *}$, in maxillofacial prosthetics ${ }^{20)}$.

The purpose of this study was to evaluate color changes in silicone maxillofacial materials after exposure to sunlight.

\section{MATERIALS AND METHODS}

The materials tested were the clear-to-translucent, high-strength, medical grade silicone rubbers, RTV and HTV. No pigments were blended with these materials in order to evaluate the color changes of the base polymer after exposure to sunlight. The manufacturer's recommendations were followed during the handling of these materials. Base elastomer silicone RTV was mixed with the curing agent in a ratio of one part of curing agent to 10 parts by weight of base materials. The unvulcanized HTV silicone gum stock comes in slabs that can be cut into weighed proportions and must be milled in a two or three roll mill to reduce viscosity and ensure a homogeneous mix.

A specially constructed two-piece aluminum mold was used to fabricate slabs of material $2 \mathrm{~mm}$ thick. The bottom of the mold had a $13.5 \mathrm{~mm}$ square cavity $2 \mathrm{~mm}$ in depth. Locking screws on each side of the mold were secured to maintain closure processing.

Approximately 75 grams of the room temperature vulcanizing silicone elastomer base was mixed with the curing agent. The mixture was stirred thoroughly for several minutes. The mixture was then exposed to a vacuum at $70 \mathrm{~mm}$ of mercury for 45 minutes in a bell jar. To help break the bubbles, the pressure was released several times. The elastomer was carefully poured into the mold and allowed to set for 30 minutes. During this time any remaining bubbles were broken with a sharp instrument. The mold was sealed and placed in a dry heat oven at $80^{\circ} \mathrm{C}$ for one hour according to Moore et al. ${ }^{21)}$ When a complete cure was achieved, the mold was quenched and the slab removed.

For the preparation of high temperature silicone slabs, approximately 50 grams uncured gum stock were milled in small increments until a homogenous mixture was achieved. A sheet of the material was removed from the mill and pressed into the mold. When the mold was slightly overfilled, thin plastic separating sheets were placed between the silicone and the top section of the mold. The mold was pressed under a force of approximately $1800 \mathrm{~kg}$ until a proper fill was verified, at which time the plastic separator sheets were removed. The mold was then fitted with the screws to maintain metal-to-metal contact. The mold was placed into a dry heat oven at $180^{\circ} \mathrm{C}$ for 30 minutes, after which it was removed and quenched in water, and the silicone specimen was removed.

Test specimens were divided into two groups : pre-exposure and post-exposure to sunlight. For this reason, two slab specimens were made for each material studied. The two specimens, HTV and RTV silicone, were fixed to a wooden frame with nails and were placed on the center of the rooftop of a building in Indianapolis and exposed to sunlight from November 1987 to May 1988 . The other two specimens were kept at room temperature in

* Silastic MDX 4-4210, DOW Corning Corp., Midland, MI, USA

** Silastic MDX 4-4515, DOW Corning Corp., Midland, MI, USA 
a dry and dark environment.

The color stability of each material was evaluated after six months by two methods: visually and by means of a chroma meter.

Visual comparisons

The specimen maintained without exposure to sunlight was compared with the exposed one of the same material by three observers. They performed three replications. In order to evaluate the color stability of each material, the specimens were evaluated with a white (\#987), a black (\#989), and a gray (\#350** background. A four-point grading scale was used: $0=$ no change, $1=$ slight change, $2=$ moderate change, and $3=$ great change.

Chroma meter comparisons

For the second evaluation of color stability, a chroma meter** was used. Readings were taken through the measuring head, processed by the built-in microcomputer, and presented digitally on the custom-designed liquid-crystal display.

The measuring head contains a high-power pulsed xenon arc (PXA) lamp which provides diffuse illumination from, a controlled $45^{\circ}$ angle with $0^{\circ}$ viewing in a $3 \mathrm{~mm}$ diameter spot. The meter's precise double-beam, feedback system detects any slight deviation in the xenon light' $\mathrm{s}$ spectral distribution, and the microcomputer compensates for them, thus ensuring utmost accuracy in measurements. The head provides a choice of two standard CIE illuminant conditions : Illuminant $C(6774 \mathrm{~K})$ and Illuminant $D_{65}(6504 \mathrm{~K})$. The former was used in this study. Reference colors and calibration standards can be entered into the memory and recalled at any time. Chromaticity can be measured in Yxy (CIE 1931) and $L^{*} a^{*} \dot{b}^{*}$ (CIE $1976)$; color difference can be measured in $\pm \Delta(\mathrm{Yxy}), \pm \Delta\left(\mathrm{L}^{*} \mathrm{a}^{*} \mathrm{~b}^{*}\right)$, and $\Delta \mathrm{E}^{*} \mathrm{ab}$.

In this study, the authors used $\mathrm{L}^{*} \mathrm{a}^{*} \mathrm{~b}^{*}$ (CIE 1976), and $\Delta \mathrm{E}^{*} \mathrm{ab} . \Delta \mathrm{E}^{*}$ ab was calculated from $\Delta \mathrm{L}^{*}, \Delta \mathrm{a}^{*}$ and $\Delta \mathrm{b}^{*}$ using the equation below :

$$
\Delta \mathrm{E}=\left[\left(\Delta \mathrm{L}^{*}\right)^{2}+\left(\Delta \mathrm{a}^{*}\right)^{2}+\left(\Delta \mathrm{b}^{*}\right)^{2}\right]^{1 / 2}
$$

The measuring points are shown in Fig. 1.

In making a statistical comparison between both before and after the 6 months aging of each specimen, sample means and standard deviations of color differences $(\Delta \mathrm{E})$ were compared using a t-test. The 6 months control and sunlight exposed specimen data were also compared using a t-test.

\section{RESULTS}

The means and standard deviations of the visual comparisons, color chromaticity $( \pm \Delta$ $\left.\left(\mathrm{L}^{*} \mathrm{a}^{*} \mathrm{~b}^{*}\right)\right)$ and color differences $(\Delta \mathrm{E})$ are presented in Tables $1-4$ and Figs. 2, 3, 4, 5 and 6. The effects of 6 months of aging at room temperature, in a dry and dark room, and the effects of 6 months of aging while exposed to sunlight are presented in Table 2. In the comparison of the specimens after 6 months under the different conditions, those means which were not

- Crescent Cardboard Co., Wheeling, IL, USA

** Minolta Chrona Meters CR-1, Minolta Camera Co., Ltd. Osaka. Japan 


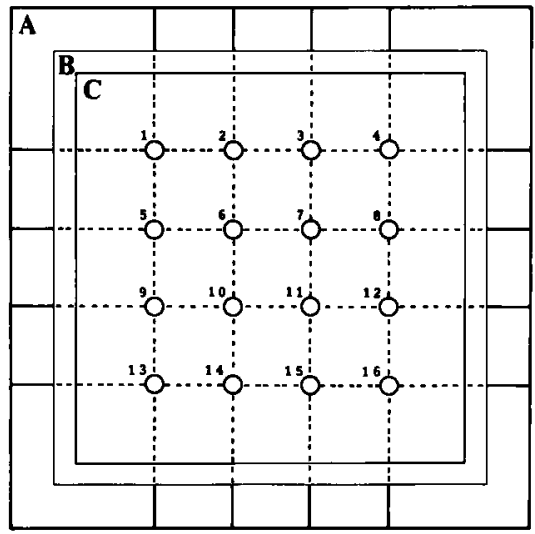
A: Standard plate
B : Background
C: specimen

Fig. 1 The measuring points of specimens.

Table 1 Visual comparison of two materials before and after exposure to sunlight

\begin{tabular}{ccccccc}
\hline & \multicolumn{2}{c}{ White } & \multicolumn{2}{c}{ Gray } & \multicolumn{2}{c}{ Black } \\
\hline & HTV & RTV & HTV & RTV & HTV & RTV \\
\hline & Con. Sun. & Con. Sun. & Con. Sun. & Con. Sun. & Con. Sun. & Con. Sun. \\
\hline Observer A & 2 & 2 & 2 & 2 & 1 & 1 \\
Observer B & 2 & 2 & 1 & 2 & 1 & 1 \\
Observer C & 1 & 2 & 1 & 2 & 1 & 2 \\
\hline X & 1.6 & 2.0 & 1.3 & 2.0 & 1.0 & 1.3 \\
S. D. & 0.57 & 0.00 & 0.57 & 0.00 & 0.00 & 0.57 \\
\hline
\end{tabular}

Grading scale : $0=$ no change, $1=$ slight change, $2=$ moderate change, $3=$ great change In comparison of two materials, there are no significant differences $(p>0.05$; Fisher exact probability test).

statistically different from each other (t-test for comparison of a single observation with the mean of a sample) have been designated by vertical lines (Tables 4 and 5).

\section{DISCUSSION}

Three parameters defined as visual comparison, color chromaticity and color difference were used to evaluate the color change of maxillofacial polymer after a 6 months aging period. The color stability test by three human observers showed that, after exposure, no specimens had more than a grade of 2 , which is considered a moderate color change. The mean values of the grading by the three human observers corresponded to values between slight color change and moderate color change. Although the HTV and RTV silicone were not significantly changed as judged by the visual comparison, the chroma meter indicated that, after exposure to sunlight, the HTV silicone showed a greater color difference than did the RTV silicone. 
Table 2 Mean values and standard deviations of the chromaticity in 6 months aging

\begin{tabular}{|c|c|c|c|c|c|c|}
\hline & & & & White & Gray & Black \\
\hline \multirow{4}{*}{$L^{*}$} & \multirow{2}{*}{ HTV } & Control & $\begin{array}{l}\text { Before } \\
\text { After }\end{array}$ & $\begin{array}{ll}52.4 & (1.00) \\
61.6 & (1.22)\end{array}$ & $\begin{array}{l}39.6(1.10) \\
44.2(0.81)\end{array}$ & $\begin{array}{ll}29.4 & (1.16) \\
27.6 & (0.48)\end{array}$ \\
\hline & & Sunlight & $\begin{array}{l}\text { Before } \\
\text { After }\end{array}$ & $\begin{array}{ll}50.3 & (1.00) \\
60.2 & (0.90)\end{array}$ & $\begin{array}{ll}39.6 & (1.10) \\
44.1 & (0.44)\end{array}$ & $\begin{array}{ll}29.4 & (1.16) \\
27.7 & (0.44)\end{array}$ \\
\hline & \multirow{2}{*}{ RTV } & Control & $\begin{array}{l}\text { Before } \\
\text { After }\end{array}$ & $\begin{array}{ll}60.4 & (1.34) \\
68.1 & (0.81)\end{array}$ & $\begin{array}{l}43.1 .(1.32) \\
47.9(0.60)\end{array}$ & $\begin{array}{ll}24.5 & (0.99) \\
26.0 & (0.67)\end{array}$ \\
\hline & & Sunlight & $\begin{array}{l}\text { Before } \\
\text { After }\end{array}$ & $\begin{array}{l}60.7 \quad(0.91) \\
65.3 \quad(0.80)\end{array}$ & $\begin{array}{ll}42.9 & (1.06) \\
46.3 & (0.47)\end{array}$ & $\begin{array}{ll}24.7 & (0.78) \\
26.4 & (0.65)\end{array}$ \\
\hline \multirow{4}{*}{$a^{*}$} & \multirow{2}{*}{ HTV } & Control & $\begin{array}{l}\text { Before } \\
\text { After }\end{array}$ & $\begin{array}{ll}-1.1 & (0.18) \\
-2.2 & (0.17)\end{array}$ & $\begin{array}{ll}-0.3 & (0.11) \\
-1.0 & (0.25)\end{array}$ & $\begin{array}{ll}-1.0 & (0.17) \\
-0.5 & (0.10)\end{array}$ \\
\hline & & Sunlight & $\begin{array}{l}\text { Before } \\
\text { After }\end{array}$ & $\begin{array}{ll}-0.8 & (0.17) \\
-2.1 & (0.10)\end{array}$ & $\begin{array}{l}-0.3(0.15) \\
-1.0(0.13)\end{array}$ & $\begin{array}{ll}-0.2 & (0.12) \\
-0.5 & (0.10)\end{array}$ \\
\hline & \multirow{2}{*}{ RTV } & Control & $\begin{array}{l}\text { Before } \\
\text { After }\end{array}$ & $\begin{array}{ll}-2.2 & (0.11) \\
-2.6 & (0.10)\end{array}$ & $\begin{array}{ll}-0.8 & (0.13) \\
-1.1 & (0.10)\end{array}$ & $\begin{array}{ll}-0.2 & (0.10) \\
-0.5 & (0.09)\end{array}$ \\
\hline & & Sunlight & $\begin{array}{l}\text { Before } \\
\text { After }\end{array}$ & $\begin{array}{ll}-2.2 & (0.11) \\
-2.6 & (0.10)\end{array}$ & $\begin{array}{l}-0.8(0.11) \\
-1.2(0.09)\end{array}$ & $\begin{array}{ll}-0.1 & (0.10) \\
-0.6 & (0.08)\end{array}$ \\
\hline \multirow{4}{*}{$\mathbf{b}^{*}$} & \multirow{2}{*}{ HTV } & Control & $\begin{array}{l}\text { Before } \\
\text { After }\end{array}$ & $\begin{array}{r}6.3(0.62) \\
10.3(0.39)\end{array}$ & $\begin{array}{l}1.0(0.45) \\
3.9(0.48)\end{array}$ & $\begin{array}{ll}-4.9 & (0.31) \\
-4.9 & (0.31)\end{array}$ \\
\hline & & Sunlight & $\begin{array}{l}\text { Before } \\
\text { After }\end{array}$ & $\begin{array}{r}4.9(0.67) \\
10.4(0.46)\end{array}$ & $\begin{array}{r}-0.3(0.35) \\
4.2(0.24)\end{array}$ & $\begin{array}{ll}-4.7 & (0.23) \\
-4.7 & (0.19)\end{array}$ \\
\hline & \multirow{2}{*}{ RTV } & Control & $\begin{array}{l}\text { Before } \\
\text { After }\end{array}$ & $\begin{array}{ll}7.7 & (0.22) \\
9.8 & (0.17)\end{array}$ & $\begin{array}{ll}3.7 & (0.28) \\
5.1 & (0.20)\end{array}$ & $\begin{array}{ll}-3.2 & (0.11) \\
-3.1 & (0.15)\end{array}$ \\
\hline & & Sunlight & $\begin{array}{l}\text { Before } \\
\text { After }\end{array}$ & $\begin{array}{r}7.9(0.19) \\
10.9(0.16)\end{array}$ & $\begin{array}{ll}3.7 & (0.29) \\
5.7 & (0.15)\end{array}$ & $\begin{array}{ll}-3.2 & (0.07) \\
-2.6 & (0.11)\end{array}$ \\
\hline
\end{tabular}

Groups connected by vertical line are not significantly different $(p>0.05 ; t$-test).

Table 3 Color difference $(\Delta \mathrm{E})$ of two materials in 6 months aging

\begin{tabular}{cccccc}
\hline & Silicone & & White & Gray & \multicolumn{1}{c}{ Black } \\
\hline \multirow{4}{*}{ Control } & HTV & $\overline{\mathrm{X}}$ & 10.4 & $\mathbf{5 . 6}$ & 2.0 \\
& & S. D. & 1.40 & 0.93 & 1.10 \\
& RTV & $\overline{\mathrm{X}}$ & 8.0 & 5.0 & 1.5 \\
& & S. D. & 1.27 & 1.62 & 0.61 \\
& & & & & \\
Sunlight & HTV & $\bar{X}$ & 11.4 & 6.1 & 4.7 \\
& & S. D. & 1.38 & 0.65 & 1.56 \\
& RTV & $\overline{\mathrm{X}}$ & 5.5 & 4.0 & 1.9 \\
& & S. D. & 0.90 & 1.25 & 0.55 \\
\hline
\end{tabular}

Comparison using a t-test, Groups means designated by the vertical line are not statistically different $(p>0.05)$. 
Table 4 Color difference $(\Delta \mathrm{E})$ of $\mathrm{HTV}$ silicone in control and sunlight at 6 months

\begin{tabular}{clc}
\hline Background & Material & $\overrightarrow{\mathrm{X}}( \pm$ S. D. $)$ \\
\hline \multirow{2}{*}{ White } & Control & $10.0( \pm 1.40)$ \\
& Sunlight & $11.4( \pm 1.38)$ \\
Gray & Control & $5.6( \pm 0.93)$ \\
& Sunlight & $6.1( \pm 0.65)$ \\
Black & Control & $2.0( \pm 1.10)$ \\
& Sunlight & $4.7( \pm 1.56)$ \\
\hline
\end{tabular}

Groups connected by vertical line are not significantly different (p>0.05; t-test).

Table 5 Color difference $(\triangle \mathrm{E})$ of RTV silicone in control and sunlight at 6 months

\begin{tabular}{clc}
\hline Background & Material & $\overline{\mathrm{X}}( \pm \mathrm{S}$. D.) \\
\hline \multirow{2}{*}{ White } & Control & $8.0( \pm 1.27)$ \\
& Sunlight & $5.5( \pm 0.90)$ \\
Gray & Control & $5.0( \pm 1.62) \mid$ \\
& Sunlight & $4.0( \pm 1.25)$ \\
Black & Control & $1.5( \pm 0.61)$ \\
& Sunlight & $1.9( \pm 0.55)$ \\
\hline
\end{tabular}

Groups connected by vertical lines are not significantly different (p>0.05; t-test).

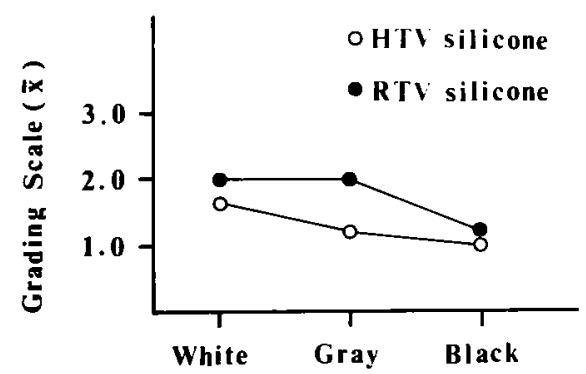

Fig. 2 The mean values of grading of three human observers.

In two of the materials which were examined against white and gray backgrounds and where the color chromaticity changed after 6 months of aging, the base elastomer of the HTV and RTV silicones was lighter than before aging. Since the base elastomer has a low contrast ratio when unpigmented ${ }^{13)}$ and is quite translucent, changes in the lightness of the base elastomer have the potential for changing the appearance of an appliance.

The changes in the $b^{*}$ values after aging were the most interesting. Both materials, HTV and RTV silicone, demonstrated an increase in $b^{*}$ values. In fact, the specimens, which 

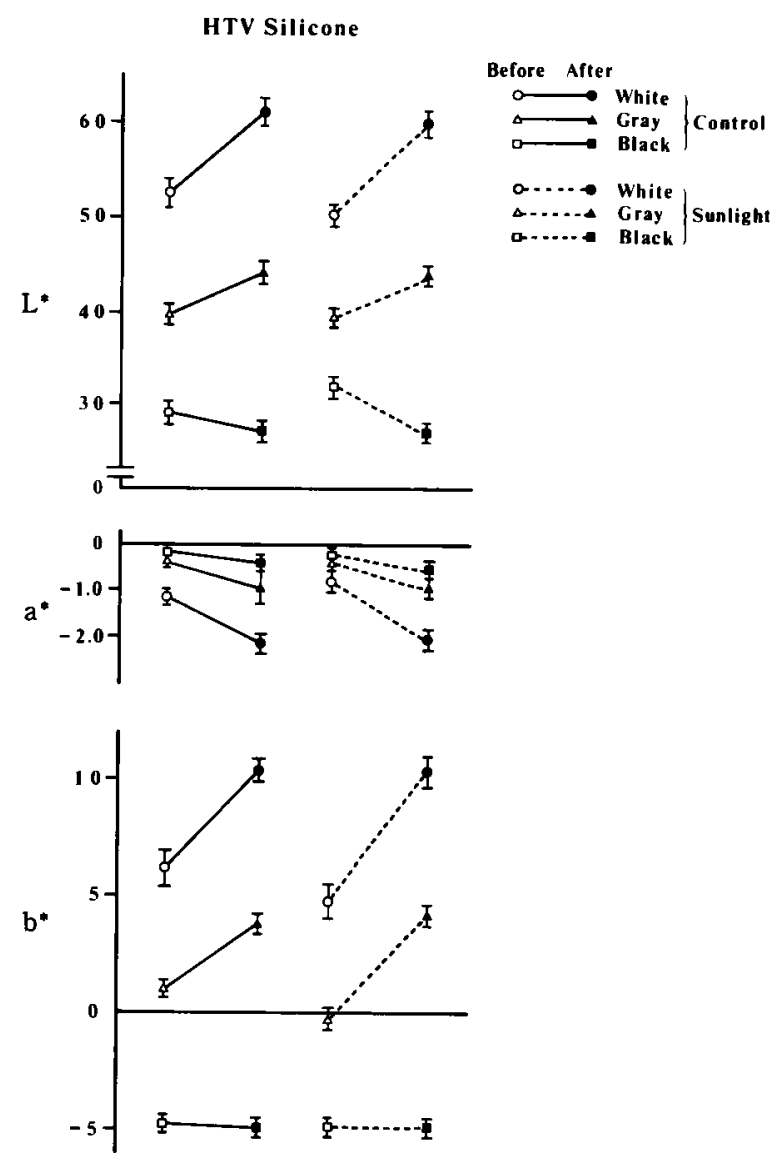

Fig. 3 Color chromaticity of HTV silicone specimens.

had been exposed to sunlight, had a "yellow like" appearance after aging. Naturally, changes of this magnitude would ruin the color of an appliance. From the results of this study, however, there was only a small difference between the control and sunlight specimens after 6 months of aging.

Some changes in color after 6 months of aging could be statistically documented. Many factors may be responsible for color stability, such as stain resistance, the chemistry of the elastomers, and the effect of handling and cleaning of the appliances by the patient. The degree of the color changes observed clinically in maxillofacial prostheses may result from staining rather than from the aging of the polymers or pigments ${ }^{14}$. From the results of this study, however, it is possible to foresee the color stability of maxillofacial base polymer. This study was limited only to the determination of the most suitable base polymers for clinical use. 

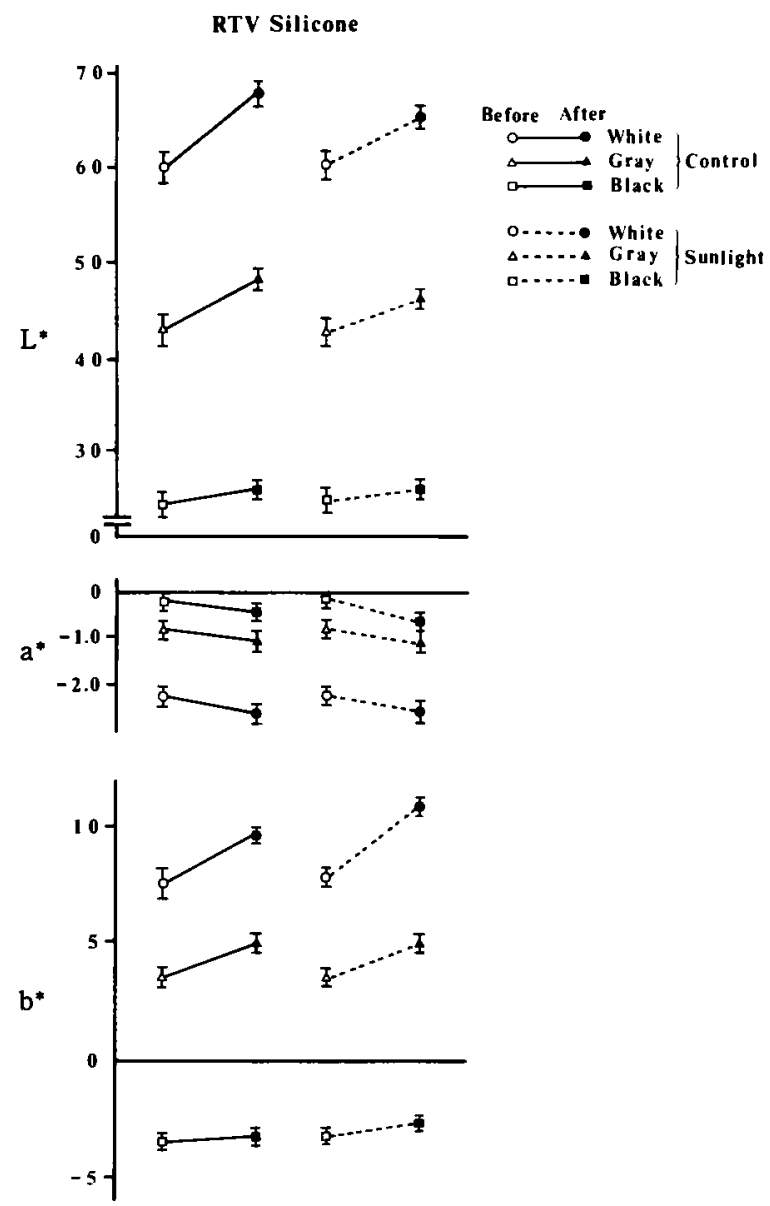

Fig. 4 Color chromaticity of RTV silicone specimens.

\section{CONCLUSIONS}

Changes in the appearance of maxillofacial prostheses in clinical service suggested that changes in the color of the polymers may be of significant concern.

The color stability of polydimethyl siloxane (HTV silicone and RTV silicone) for maxillofacial applications was investigated by comparing the effects of 6 months of aging at room temperature in a dry and dark room to the effects of aging through exposure to outside conditions, especially sunlight.

The evaluations resulted in the following conclusions.

1. The RTV and HTV silicone were not significantly different after aging, as judged by visual observation.

2. On each specimen, control and sunlight, there were relatively large differences in the chromaticity after 6 months of aging of the specimens when examined against a white and 


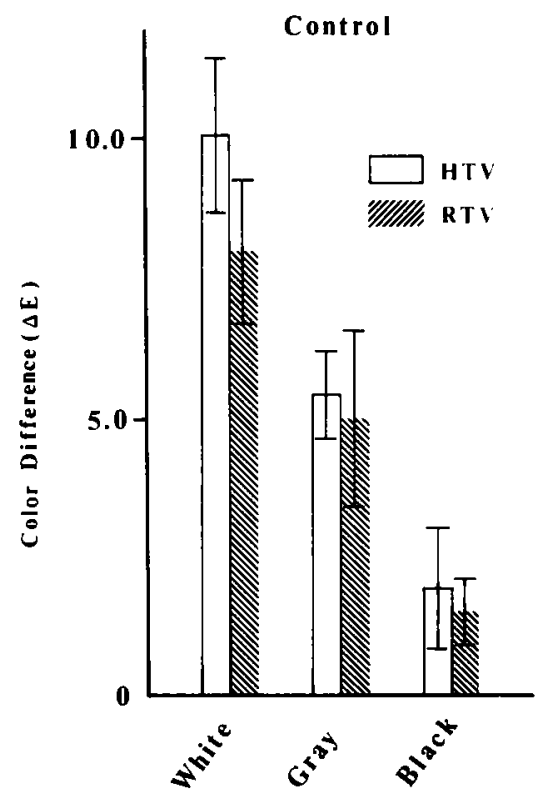

Fig. 5 Color difference of control specimens.

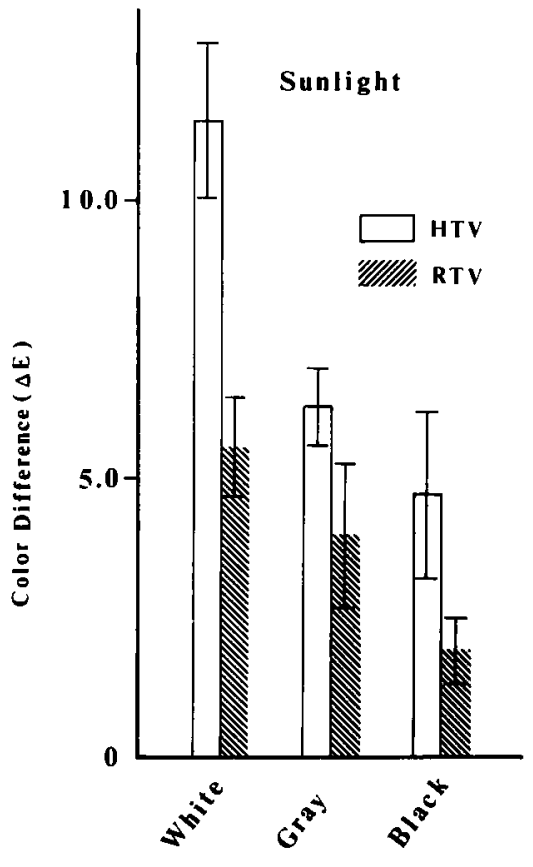

Fig. 6 Color difference of sunlight specimens, 
gray background.

3. In a comparison of the color difference test results of the sunlight specimens at 6 months, the HTV silicone showed a larger difference than RTV silicone against the three backgrounds. On the other hand, in the color difference results of the control specimens the HTV silicone showed a larger difference than RTV silicone only against the white background. 4. Color changes as a result of exposure to sunlight for both HTV and RTV were quite small compared to the effects of 6 months of aging.

These results indicate that sunlight and the environment may not be responsible for the color changes which necessitate the replacement of appliances. This study, however, suggested that aging rather than exposure to sunlight results in most of the color changes observed in the HTV and RTV base polymers studied.

\section{ACKNOWLEDGMENT}

The authors gratefully acknowledge Dr. Ralph W. Phillips, Department of Dental Materials, School of Dentistry, Indiana University and Dr. Charles J. Goodacre, Department of Prosthodontics, School of Dentistry, Indiana University, for their helpful counseling and encouragement.

\section{REFERENCES}

1) Rahn, A. O. and Boucher, L. J. : Maxillofacial prosthetics, principle and concept, 1st ed., W. B. Saunders Co., Philadelphia, 1970, pp. 21-22.

2) Chalian, V.A. : Evaluation and comparison of physical properties of materials used on maxillofacial prosthetics, Master's Thesis, Indiana University, 1976.

3) Lewis, D. H. and Castleberry, D. J. : An assesment of recent advances in external maxillofacial materials, $J$ Prosthet Dent 43(4): 426-432, 1980.

4) Fonceca, E. P.: The importance of form, characterization, and retention in facial prostheses, $J$ Prosthet Dent 16(2): 338-343, 1966.

5) Cantor, R., Webber, R. L., Stroud, L. and Ryge, G. : Methods for evaluating prosthetics facial materials, $J$ Prosthet Dent 21(3) : 324-332, 1969.

6) Ouellette, J. E. : Spray coloring of silicone elastomer maxillofacial prostheses, $J$ Prosthet Dent 22(2) : 271-275, 1969.

7) Shaaf, N.G. : Color characterizing silicone rubber facial prostheses, $J$ Prosthet Dent 24(2): 198-202, 1970.

8) Bartlett, S. O., Pineda, L. Y. and Moore, D. J. : Surface characterization of the silicone rubber prosthesis, $J$ Prosthet Dent 25(1): 69-71, 1971.

9) Craig, R. G., Koran, A., Yu, R. and Spencer, J.: Color stability of elastomers for maxillofacial appliances, $J$ Dent Res 57(9, 10): 866-871, 1978.

10) Koran, A., Yu, R., Powers, J. M. and Craig, R. G. : Color stability of a pigmented elastomer for maxillofacial applications, $J$ Dent Res 58(5) : 1450-1454, 1979.

11) Koran, A., Powers, J. M., Lepeak, P. J. and Craig, R. G. : Stain resistance of maxillofacial materials, J Dent Res 58(5): 1455-1460, 1979.

12) Goldberg, A. J., Craig, R. G. and Filusko, F.E. : Ultraviolet light stability of external maxillofacial prosthetic materials, Abstr., IADR Program and Abstr. of papers 55: B138, 1976.

13) Craig, R. G., Koran, A. and Yu, R. : Color stability of elastomers for maxillofacial appliances, $A b s t r$, IADR Program and Abstr of papers 56: A173, 1977.

14) Craig, R. G., Koran, A. and Yu, R.: Elastomers for maxillofacial applications, Biomaterials 1 April : $112-117,1980$. 
15) Duncan, J. D. and Rommerdale, E. H. : Base shade determination of a new elastomer for maxillofacial prostheses, $J$ Prosthet Dent 44(6) : 654-655, 1980.

16) Turner, G. E., Fischer, T. E., Castleberry, D. J. and Lemons, J. E. : Intrinsic color of isophorone polyurethane for maxillofacial prosthetics, Part I : Physical properties, $J$ Ptosthet Dent 51(4): 519-522, 1984.

17) Turner, G. E., Fischer, T. E., Castleberry, D. J. and Lemons, J. E. : Intrinsic color of isophorone poly. urethane for maxillofacial prosthetics, Part II : Color stability, $J$ Prosthet Dent 51(5) : 673-675, 1984.

18) Phillips, R. W., Margets, P. M., Urban, J. J. and Leonard, F. : Materials for the fabrication of maxillofacial prostheses, In Chalian, V. A., Drane, J. B. and Standish, S. M. : Maxillofacial prosthetics, Multidisciplinary practice, 1st ed., The Williams and Wilkins Co., Baltimore, 1972, pp. 89-107.

19) Sweeny, W. T., Fischer, T. E., Castleberry, D. J. and Cowperthwaite, G. F. : Evaluation of improved maxillofacial prosthetic materials, $J$ Prosthet Dent 27(3) : 297-305, 1972.

20) Koran, A. and Craig, R.G.: Dynamic properties of maxillofacial materials, $J$ Dent Res 54(6): 1216 $-1221,1975$.

21) Moore, D. J., Glazar, Z. R., Tobacco, M. J. and Linebaugh, M. G. : Evaluation of polymeric materials for maxillofacial prosthetics, $J$ Prosthet Dent 38(30): 319-326, 1977. 
ポリカルボン酸を含む歯科用セメントと歯質との接着機構

電位差滴定からみたカルシウム共存下におけるセメントポリマーの高分子電解質挙動

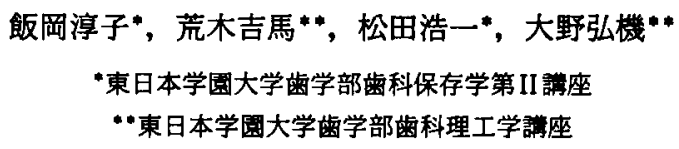

種々な湌度のカルシウムイオンが共存するポリアクリ ル酸およびポリカルポン酸系セメントから分離したポリ マー水溶液の電位差滴定を $\mathrm{NaOH}$ 溶液で行った。その 結果, これら高分子電解質は，カルシウムイオンが共存 しない場合にはいずれも弱酸的挙勘を示した。ところが， ポリマー中のカルボン酸基の䍜度に対して $1 / 2$ 当量以上 カルシウムイオンを共存させると, 各ポリマーは強酸型
の挙動を示した。つまり，このことはアルカリによって カルボン酸を中和してゆくと，解離したカルボキシレー トイオンが共存するカルシウムイオンと強く結合するを 意味している。

したがって,このような挙動は，セメントと霓の間 で起るとされる化学的接着の機軗として有力なものと考 えられる。

義菌床用材料（PMMA）の疲労特性に関する研究

\title{
藤井孝一 \\ 鹿児島大学菌学部歯科理工学讙座
}

義崡床用材料 (PMMA)に咸して，曲げ疲労試験及び 引張疲労試験を行った。さらに引張疲労試験に伴う粘弾 性と引張特性の変化を調へた。

その結果, 疲労試駼後の破面の比较では, 曲げ疲労に よる破面は, 引張側の表面からクラックが開始し，その 後のクラックの進行を表わす striation が現察され，破壊 にいたるという様相を示す。一方, 引張疲労の場合にも 類似の傾向が認められる。

疲労に伴う粘弾性の変化については，疲労が進むと貯 藏弾性率 $\left(E^{\prime}\right)$ は, 湘定されたすべての温度領域で低下
する。一方, 損失弾性率 $\left(\mathrm{E}^{\prime \prime}\right)$, 損失正接 $(\tan \delta)$ はわ ずかづつ増加する傾向を示した。また, 弾性率, 引張強 さ，䩞性などは，10‘回の繰り返し数で，すでに低下を示 していた。これらの結果は, 疲労に伴うクラックの発生 が材料の劣化を招いたものと考えられる。

義歯床用材料として使用されている 4 種類の市販品の 疲労特性を調へた。流し込み型レジンの疲れ強さは加熱 重合型より小さく，材料間で大きことなる。このばら つきの一因として，材料組成の違い，末反応物貝の量の 連いなどが考えられる。

屋外直接暴露試験によるエピテーゼ用シリコーンラバーの変色に関する研究

\author{
鷹股折也*, B. Keith Moore**, Varoujan A. Chalian*** \\ "松本歯科大学崡科補緅学第一㜔座 \\ - Dental Materials, School of Dentistry, Indiana University \\ **Maxillofacial Prosthetics, School of Dentistry, Indiana University
}

エピテーゼ用材料はその使用目的から，顔面皮虍との 色調の調和, 皮问類似性の柔軟性と自然感, 生体親和性 と物理化学的な安定性, 成形か!容易で彩色に優れている ことなどの諸性質が必要とされる。特に, 顔面補緅では, 機械的な劣化以上に，変色が原因で再製作を余儀なくさ
れる場合が多いといわれる。変色の要因あるいは原因は いろいろ考えられるが, これらを検討するには，着色し ていないベースポリマーと着色・彩色の施されているエ ラストマーについてそれぞれ考虑しなければならない。 本研究では，着色・彩色のされていないペースポリマー 
自体の変色について,色彩の変化を測定することにより， その結果, 常温加硫シリコーン, 加熱加硫シリコーン共 色彩学的な観点から考察する目的で 6 か月間屋外直接暴 に, 太陽光線の影留よりも, 経日的な影響か強い傾向が

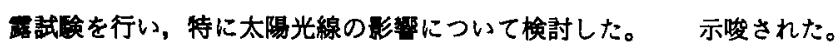

